\title{
Organization of Descriptive Writing with Reference to the Writings of the Students of Certificate Course in English for School Leavers, Uva Wellassa University of Sri Lanka
}

\author{
G.H. Abeyweera
}

Department of English Language Teaching (DELT), Uva Wellassa University of Sri Lanka, Badulla, Sri Lanka

Received: 29 Jan 2021; Received in revised form: 09 Apr 2021; Accepted: 03 May 2021; Available online: 23 May 2021 (C2021 The Author(s). Published by Infogain Publication. This is an open access article under the CC BY license (https://creativecommons.org/licenses/by/4.0/).

\begin{abstract}
This research papers attempts to discuss the organization of fifty descriptive writings by the students of Certificate Course in English for School Leavers (CCESL) offered by the Centre for Open \& Distance Learning of Uva Wellassa University of Sri Lanka. This discussion is carried out through qualitative analysis of schematic organization, choice of the themes and themes development. Amongst many elements required for any piece of writing to be well accepted, organization of a written text is a salient element in producing a meaningful and purposive text. Thus, knowing the students' competency in writing an accepted text would be worthwhile to assess the standard of writing. For this research, a qualitative approach is applied by employing a few theories proposed by Gerot and Wignell (1995), and Eggins (2004) respectively. It is interesting to find that most of the students are familiar with local and topical themes while hardly any number paying attention to foreign text familiarity. However, thematic development and repeating chosen them seem common in their writing. Based on the discussion of writings of the students of CCESL, it was found that the organization of their writing was more perfunctory and less organized as a considerable number of written texts do no have either beginning and end or middle or one of the three elements. Further, their writing seems to be dull as they were not employed myriad sentence structures in their writing which in other terms reveal that their skills in writing has to be improved to a satisfactory level. As a remedy, it is suggested that students ought to undergo a rigorous practice in writing to learn as to how to organize their ideas on given texts in producing descriptive written discourses.
\end{abstract}

Keywords - choices, ideas, descriptions, organization, writings.

\section{INTRODUCTION}

Although English Language is taught as Second Language (ESL) in the context of Sri Lanka which is now the medium of higher education, research (Arnet, L.2001 \& Jonson, S. 1996)) has proved that it is needed further emphasis on Teaching English as a Second Language. There are basic elements which are called skills in a given language that one has to master in mastering a language. The four skills (both Receptive \& Productive skills) listening, reading and then speaking and writing are salient in mastering a language including English Language. Among these four skills writing skills which is a productive skill is considered as one of the most difficult elements for a Second Language Learner as well as for one who learns English as a foreign language (Andrade, M.S., Evens, N.W., 2012). The difficulties that one finds are due to many aspects beginning from the use or selection of words, accurate grammatical compositions, typology, punctuation to the more complex aspects of writing such as generating ideas and organizing these ideas together in logical manner in producing meaningful descriptive texts.

Writing a piece of writing is not just to communicate one's ideas by employing grammatical structures. It is also not just putting one's ideas in a string of words. Writing a 
piece of writing on any give topic is more than that. It is truly organizing one's ideas on a given topic in a logical manner in which precision, clarity, sense, objective and readability are included to produce an understandable written corpus which is called organization of a written text (Grossman, R.B. \& Goody, J. 2002, 1996).

Organization in writing is one of the considerations of some expertise. For instance, Philip Angela (2007) exemplifies the organization of written text as, it is the organization of all the syntactical compositions having together in which the whole generated idea is logically and precisely linked to the next point of reference in the sentence. Manser (2006) also argues that ultimate organization of a written text ought to produce sense of writing and thereby making it meaningful.

There are two ways of analyzing the organization of the text as per the description of Thornberry (2005) where he concentrates on writing in several stages such as unlocking text, what makes a text, what makes a text makes sense, spoken texts, texts in contexts, classroom texts, learner texts and them classroom activities where he analyzes a text in terms of both text's logical organization and also looking at the lexical arrangement of a text.

The sample texts were analyzed by employing schematic structure in determining the nature or the type of the text and then thematic choice to determine how learners produce written texts and finally them development to determine how learners organize their texts by employing frequently used manner of constructions.

\section{METHODOLOGY}

A qualitative research methodology was used to describe the organization of students' writing through schematic structure, thematic choices and thematic development shaping their writing in the in manner of employment of words. for this, fifty leaners (all the students) of the CCESL were selected and the data collection was done by informing them that their written assignments be used for this particular purpose for ethical clearance. Then on the order of their registration, several steps: scrutinizing texts, analyzing the schematic structure of each text of the learners of CCESL, parsing each text into clauses, pointing out thematic choices, and analyzing thematic development and them presenting data based on applied theories and reaching conclusion were taken in this research.

\section{DISCUSSIONS}

According to the analytical description of the fifty students writing, it was revealed that most of the students were interested in studying the literary texts prescribed for their reading where students are asked to produce critical description on given texts in writing. In these fifty descriptions based on the text "Marriage is a Private Affair" by Chinua Achebe, the thesis, argumentation and repeating the thematic statements were found. According to Gerot and Wignell (1994), a thesis of a text should be comprised of the writer's position and preview. The first five learners out of fifty learners in the course, "The short story is interest/ ing / ed because it speaks/talk/say about two/2 generationa". From these sentences as they were written exactly in the way stated (remember there are number of sentences written in different ways), the position of the learners was clear that almost all preferred the selection of the text as to why they attempted to compose the same sentence in different ways with syntactic mistakes and errors. Thus, the preview of the learners is also noteworthy as the phrase 'story is interested/ ing'. The examiner has to guess the complete sense of the whole sentence construction as the very sentence contains numerous mistakes. Because of the very reason, the organization of the sentence/ text is not in logical sequence.

Then turning into learners' arguments over the critical essay given to them on the same short story, most of the students, 41 out of fifty students described the fact that it is about a conflict between two generations and they supported for the younger generation than that of the old which might be due to the fact that these fifty respondents belong to a age group of 23 to 26 who are having the same view.

It is also noteworthy observe the thematic choice of their writing. The finding of their writing suggests the fact that precisely there are a few themes recognized through their writing. The themes such as the generation gaps, conflict between two generations, attitudes of both young and old, realization of life with the passage of time, qualities for being a good wife, the religious upbring etc. were identified as major themes of their writings.

The thematic development also was observed in their writing as they dealt with in length of the identified theme of the text by the learners. What is remarkable is that these themes were substantiated by providing several arguments to justify what they assumed them to be. The organization of the texts as their answers seems quite annoying. As stated before, the organization occurs where the interpretation of some elements in the written discourse is dependent on that of another. Among fifty learns of the CCESL 32 learners found to be making syntactical mistakes reflecting the fact that the need of further training on writing in order to organize a well cohesive and organized test. 
In general, several mistakes were found in most their writing which cause for not producing organized texts. Identifying themes were really impressive whereas the thematic development and the reiteration of themes were not in the expected level of satisfaction implicating several impending dangers of the meaningless production in their writings. Further, the study reveals the fact that the theme reiteration was mainly used for it is easy for the learners, especially novice students to organize their ideas not syntactically accurate though by using the same theme identified at each attempt.

\section{CONCLUSION}

The students/ learners of CCESL used their syntactic and semantic awareness to their maximum in their answers to the given assignment which in return provides an overall picture of the standard of usage of language. Although they have identified certain thematic structure, thematic development and argumentation in their production, there can not be seen a well-knit organization of texts producing meaningful texts for they have numerous syntactic, semantic, typological mistakes and errors. It is also noteworthy to note that thematic reiteration was the most dominant fact used by the most of the learners of the programme for it is the easiest way of developing the text production erroneous though. In conclusion, learners written text were less organized as many written texts have incomplete thesis statements, lack of analytical descriptions, less logical sentence contractions etc. Further, from the perspective of thematic development, the over use of reiteration due to lack of vocabulary, diverse sentence contractions patterns, lexical diversity etc. which depict the fact that learners' writing skills are comparatively at a poor stage for they find it difficult to illustrate their ideas my means of various methods.

\section{SUGGESTIONS}

For the novice learners, they ought to undergo rigorous practice to learn how different types of written text developments are organized in a coherent and organized style which will train them producing well organized texts. It is also suggested that different method in thematic choices and thematic development be employed in teaching written text developments which is the logical organization of texts. In addition, clear instructions, relevant materials and guidebooks also should be recommended for the learners. Finally, future researchers too have to find out novel methods in which learners are trained in developing organized texts.

\section{REFERENCES}

[1] Goody, J. (2006). The Logic of Writing and Organization of Society. Cambridge University Press

[2] Grassman, R.B. (2002). The Art of Writing Reasonable Organic Reaction Mechanisms, Springer Publication

[3] Lessow-Hurley, J. (2003). Meeting the Need of Second Language Leaners: An Educator's Guide. MacMillan Publications

[4] Arnet, L. (2001). English As a Second Language (Quickstudy Reference Guide-Academic)

[5] Sage Publications

[6] Phillips, A. (2007). Good Writing for Journalists. Sage Publications

[7] Manser, M.H. (2006). The Facts on File Guide to Writing. Penguin Publishers

[8] Efron, S.E., Ravid, R. (2019). Writing the Literature Review: A Practical Guide. Guilford Press

[9] Levkowitz, Osvaldo N., Oliveira Jr (eds.). (2014). Writing Scientific Papers Successfully: Your Complete Road Map. Hyprtek.com Inc.

[10] Jossey-Bass. (2016). English Language Arts. Writing Module: Teacher Guide: Argument Writing. Routledge Publication

[11] Oshima, A., Hogue, A. (2006). Academic Writing English. $4^{\text {th }}$ Edition. Longman Publication 